I. V. SAKHANDA ${ }^{l}$, K. L. KOSYACHENKO ${ }^{1}$, T. S. NEHODA ${ }^{1}$, A. V. KABACHNA ${ }^{2}$, L. L. DAVTIAN ${ }^{2}$, V. V. GLADYSHEV ${ }^{3}$, I. V. GLADUKH $H^{4}$ (Kyiv, Zaporizhzhia, Kharkiv; Ukraine)

\title{
COMPARATIVE PHARMACOECONOMIC RESEARCH AND EVALUATION OF ENALAPRIL GENERICS IN TREATMENT OF PATIENTS WITH ARTERIAL HYPERTENSION
}

\author{
${ }^{1}$ Bogomolets National Medical University, Kyiv; ${ }^{2}$ Shupyk National Medical Academy \\ of Postgraduate Education, Kyiv; ${ }^{3}$ Zaporizhzhia State Medical University, Zaporizhzhia; \\ ${ }^{4}$ National University of Pharmacy, Kharkiv <sahanda.ivanna@ukr.net>
}

\begin{abstract}
The number of people with cardiovascular diseases has increased significantly in recent years. According to statistics, diseases of the cardiovascular system occupy one of the first places among other diseases. One of the main pathologies in cardiology is hypertension. Treatment of arterial hypertension for a long period remains an important medico-social and economic task, a heavy financial burden falls on the patient himself or on the health care system, in the case of free distribution of drugs. The group of antihypertensive drugs is one of the most expensive, which raises the question of cost-effective therapy. Clinical and economic research that combines analysis of clinical efficacy and affordability is necessary for evidence-based, rather than empirical, choice of the drug. The most acceptable method of assessing the clinical significance of various drugs is a "cost-effectiveness" analysis. The article is devoted to the conducted pharmacoeconomic research, giving a comparative assessment of various enalapril generics. The objective of the work was to identify and justify the use of the most clinically effective and cost-effective generic drugs enalapril. The methodological basis of the research was the modern concept of marketing research of the drug market, the methodology of system analysis and scientific forecasting of economic phenomen. In the process of research, the methods of system, sociological, economic and statistical analysis, including absentee questionnaires, were used. As a result, sales of cardiovascular drugs on the pharmaceutical market were analyzed, the structure of enalapril generic consumption in health facilities was studied, and a pharmacoeconomic analysis ("cost-effectiveness» method) of antihypertensive treatment of enalapril generics was conducted.
\end{abstract}

Key words: pharmacoeconomic analysis; «cost-effectiveness»; arterial hypertension; blood pressure; generics; enalapril.

Introduction. Rapid development of the pharmaceutical market in our country has led to the appearance of a large number of generic drugs. Nowadays, the number of generics, according to different authors, reaches $90 \%$ [1]. Original drugs are drugs that came into circulation with their own registered names. Reproduced medicinal products are medicinal products that have come into circulation after the expiry of the exclusive patent rights for original medicinal products [6]. The original drug (brand-name drug) is first synthesized and completed a full cycle of clinical trials drug, whose active ingredients (method of preparation, indications for use, trade name) are protected by a patent for a certain term. Reproduced medicinal product (generic drug) is a medicinal product having a proven therapeutic interchangeability with an original medicinal product of a similar composition manufactured by another manufacturer. Generics are allowed in a sale after the expiration of the original drug patent protection and undergo a brief registration scheme and an assessment of bioequivalence.

Pharmaceutical manufacturing companies of original drugs spend a huge amount of time and money on drugs manufacturing, analyzing the clinical effectiveness and safety of their drug, as well as on the patenting procedure and registration $[1,7]$. 
Manufacturers of generic drugs are actively promoting their products, not always proving its therapeutic equivalence to brands. Therefore, it is difficult to assess the objectivity of information about generics, on the basis of which a doctor or pharmacist can decide to replace one analogue with another without harming the patient [6]. The generic preparation can only be considered equivalent to the original one when it is similar in three characteristics: pharmaceutical, pharmacokinetic and therapeutic equivalence. However, the question of the therapeutic equivalence of the reproduced medicinal products is often left open, since comparative clinical trials of generics and brand-name drugs are not compulsory at present, and the conclusion about the drug is made on the basis of pharmaceutical and pharmacokinetic equivalence [1]. It should be borne in mind that the study of bioequivalence only suggests that generics pharmacokinetically equivalent to the original drugs provide the same efficacy and safety of pharmacotherapy [8].

Considering the low price, the reproduced medicinal products gained popularity with the organizers of drugs procurement for medical organizations of state form of ownership. The vicious practice of short-term saving of financial resources for a medical organization, as a rule, results in large economic losses in the future in the provision of medical care. The vicious practice of short-term saving of financial resources for a medical organization, as a rule, results in large economic losses in the provision of medical care in the future. This paradox is largely due to the lack of equivalent clinical effectiveness between generics and brands. This usually leads to a longer stay of patients in the hospital, the use of higher therapeutic doses of medications, as well as to the additional costs for replacing the drug, in case if it is ineffective, and for the prevention of undesirable side effects.

On the other hand, practicing doctors and patients are not always well informed about the merits and demerits of generic drugs, although it is the doctor, like no other, that should be primarily aware of the quality of the drug that he appoints to the patient. If the treatment is ineffective, the claims are fairly justified to the treating doctor, not the manufacturer. Lacking reliable information about the equivalence of brands and generics, both doctors and patients come to their own opinion about the drug by trial and error.

The problem of choosing between the original drugs and generics appears when using any classes of drugs. It also occurs in the treatment of hypertension.

The treatment of arterial hypertension over a long period remains an important medical, social and economic task, which falls heavily on the patient himself or on the health care system, in case of free of charge medication dispensing. The popularity of angiotensin-converting enzyme (ACE) inhibitors in the treatment of arterial hypertension among physicians and patients is well founded. Due to a wide range of generic drugs on the market of ACE inhibitors, the issue arose regarding the interchangeability of these drugs and therapeutic equivalence with the brand [5-7].

For a scientifically based choice of a drug, it is necessary to conduct clinical and economic studies combining the analysis of clinical efficacy and economic accessibility. The most acceptable method for assessing the clinical significance of various drugs is the «cost-effectiveness» analysis [4]. Based on the above, we conducted a clinical and economic study on the comparative evaluation of various generics of enalapril.

The purpose of this study was to identify and justify the use of the most clinically effective and economically feasible enalapril generic drug for inclusion in the formulary of Kyiv medical organization.

During the research the following tasks were solved:

- to study the situation on the pharmaceutical market of cardiovascular drugs in Kyiv;

- to analyze the structure of consumption of enalapril generics in medical organizations in Kyiv; 
- to conduct a pharmacoeconomic analysis of antihypertensive therapy with generic drugs of enalapril in Kyiv clinics.

Methodology. Sales volume of cardiovascular drugs and ACE inhibitors were studied using analysis of annual reports in the structure of retail and wholesale turnover.

Analysis of the structure of enalapril generics consumption was conducted based on the results of the questionnaire of doctors and patients, as well as on the analysis of the case histories for 2016. The obtained data formed the basis of clinical research.

Research design is an open, comparative, short-term study of the clinical and economic effectiveness of enalapril generic drugs: enam (Dr. Reddy's Laboratories, India), ednit (Gedeon Richter, Hungary), enap (KRKA, Slovenia), enalapril (Novomed, Russia).

The study included 683 patients with a diagnosis of hypertension.

Subsequently, the patients were divided into 4 groups depending on the drugs used. To achieve the greatest homogeneity possible of the compared groups, exclusion criteria were defined: myocardial infarction in case history, the development of side effects with the use of ACE inhibitors and the need to switch to another class of antihypertensive drugs.

The average age of patients separately for women and men in groups receiving different drugs is shown in Table 1.

Table 1. The average age of patients in different groups of generics

\begin{tabular}{l|c|c|c|c}
\hline \multirow{2}{*}{ Gender } & \multicolumn{4}{c}{ Age of patients (years, $M \pm \sigma$ ) } \\
\cline { 2 - 5 } & Enalapril & Enap & Enam & Ednit \\
\hline \hline Women & $66,3 \pm 2,0$ & $63,9 \pm 2,0$ & $59,8 \pm 1,8$ & $60,1 \pm 1,8$ \\
Men & $61,4 \pm 4,4$ & $59,8 \pm 3,2$ & $56,5 \pm 3,2$ & $60,3 \pm 2,8$ \\
\hline
\end{tabular}

Treatment was carried out in the form of monotherapy with enalapril generics. The duration of medical observation, including hospitalization and the following attendance of doctors, was 2 months. According to the literature, rapid increase of the dose of ACE inhibitors is not recommended, since over time the effectiveness of antihypertensive therapy in many patients is increased even with the use of small doses of the drug. You can increase drug dose only in 4 weeks in case if blood pressure is not normalized $[2,7]$.

The effectiveness evaluation was carried out for four generics.

The effectiveness of therapy was assessed by surrogate points, that is, by reducing systolic and diastolic blood pressure.

A cost-effectiveness analysis was chosen to assess the economic effectiveness of the therapy.

For the analysis, direct medical costs were used - the cost of a two-month therapy, taking into account the average retail prices of drugs in rubles, which were centrally supplied to the clinics under study. The cost of the average dose of drugs was calculated and the price of the course of treatment was determined. The source of prices for medicines is the average retail prices of pharmacies for 2016. Direct non-medical and indirect costs were not taken into account, as all patients received a standard laboratory-diagnostic examination.

Then the calculation of the clinical effectiveness and economic feasibility of the drugs was carried out using the «cost-effectiveness» analysis, and "cost-effectiveness" indicators were obtained reflecting the ratio of the real drug costs to its effectiveness. The smaller this indicator was, the more clinically expedient and economically expedient the given drug was.

Results and discussion. The situation in the wholesale and retail market of medicines confirms the high adherence of patients to the use of ACE inhibitors. On the 
pharmaceutical market in Kiev, this group of drugs takes the first place in sales of cardiovascular products, and the leader in sales within the group is INN enalapril.

A similar situation can also be observed with patients concessional support of the decreed group. The share of enalapril accounts for $50 \%$ from the group of ACE inhibitors.

Among the generics of enalapril, the leading position in retail turnover is occupied by the drug enap of the company KRKA, followed by ednit of Gedeon Richter with close sales figures. The list of reproduced preparations of enalapril continues with enam (manufacturing company Dr. Reddy's) and enalapril (various manufacturers).

The average daily doses of the preparations are indicated in Table 3 . As a result of the pharmacoeconomic analysis, the obtained data is presented in Table 2.

The obtained data made it possible to identify the leaders in terms of clinical effectiveness. They were ednit and enalapril. These drugs showed similar levels of systolic blood pressure reduction (by 25,33 and 24,21\%) and diastolic blood pressure reduction (by 17,14 and 16,45 \%) at dosages of 22,5 and $19,6 \mathrm{mg}$, respectively.

Table 2. Indicators of clinical and economic efficiency of enalapril generic drugs according to pharmacoeconomic research

\begin{tabular}{l|c|c|c|c|c|c}
\hline Drug & Company & $\begin{array}{c}\text { Average } \\
\text { dose, mg }\end{array}$ & $\begin{array}{c}\text { Systolic } \\
\text { blood pres- } \\
\text { sure reduc- } \\
\text { tion, \% }\end{array}$ & $\begin{array}{c}\text { «Cost/ } \\
\text { effective- } \\
\text { ness» } \\
\text { indicator }\end{array}$ & $\begin{array}{c}\text { Diastolic } \\
\text { blood } \\
\text { pressure } \\
\text { reduction, \% }\end{array}$ & $\begin{array}{c}\text { «Cost/ } \\
\text { effective- } \\
\text { ness» } \\
\text { indicator }\end{array}$ \\
\hline \hline Ednit & Gedeon Richter & 22,5 & 25,33 & 32,78 & 17,14 & 38,87 \\
Enap & KRKA & 23,1 & 20,1 & 34,18 & 14,33 & 39,11 \\
Enam & Dr. Reddy's & 22,1 & 18,44 & 37,55 & 10,1 & 54,84 \\
Enalapril & «Novomed» & 19,6 & 24,21 & 7,12 & 16,45 & 9,68 \\
\hline
\end{tabular}

Pharmacoeconomic calculations made it possible to reveal the following picture: enalapril takes the first place and further, with the minimal difference, ednite and enap are located. Enam showed low clinical efficacy and, as a result, a high «cost-effectiveness», despite the lower cost, in comparison with other generics. Since, in order to achieve the target level of blood pressure reduction, it was necessary to adjust the dose toward its increase, which, despite the low cost of this drug, led to a significant increase in the cost of treatment. Therefore, from a pharmacoeconomic point of view, enam is the least preferred drug [4-6]. According to our research, $18 \%$ of patients with an enam had unwanted side effects, which manifested itself as dry cough and allergic reactions.

Conclusions. According to the frequency of prescriptions, «Enap» of the company KRKA takes the first place in the treatment of hypertension in Kyiv from Enalapril generics analogs.

\section{References}

1. Белоусов Ю. Б., Зырянов С. К. Дженерики или бренды: pro et contra // Качественная клин. практика. - 2003. - № 2. - С. 95-100.

2. Ивлева А. Я. Клиническое применение ингибиторов ангиотензинпревращающего фермента и антагонистов ангиотензина II // Консилиум. - 2003. - Т. 5, № 11. C. 641-648.

3. Корзун А. И., Кириллова М. В. Сравнительная характеристика ингибиторов ангиотензинпревращающего фермента // Экология человека. - 2003. - № 2. - С. 16-22.
1. Belousov Yu. B., Zyryanov S. K. Dzheneriki ili brendyi // Kachestvennaya klin. praktika. - 2003. - № 2. - P. 95-100.

2. Ivleva A. Ya. Klinicheskoe primenenie ingibitorov angiotenzinprevrashchayushchego fermenta i antagonistov angiotenzina II. // Konsilium. - 2003. - T. 5, № 11. - P. 641648.

3. Korzun A. I., Kirillova M. V. Sravnitelnaya harakteristika ingibitorov angiotenzinprevraschayuschego fermenta // Ekologiya cheloveka. - 2003. - № 2. - P. 16-22. 
4. Леонова М.В. Выбор антигипертензивных препаратов с наименьшей стоимостью // Фарматека. - 2003. - № 6. - С. 34-38.

5. Мариевич С. Ю., Шальнова С. А., Якусевич B. В. и др. Сравнительное изучение эффективности двух препаратов эналаприла малеата у больных с мягкой и умеренной артериальной гипертонией // Кардиоваскулярная терапия и профилактика. - 2003. - № 2. - С. 33-37.

6. Недогода С. В., Сабанов С. В. Фармакоэкономика артериальной гипертензии: от глобального к частному // Пробл. стандартизации в здравоохранении. Бюл. клин.эконом. анализа. - 2003. - № 2. - С. 25-29.

4. Leonova $M$. V. Vyibor antigipertenzivnyih preparatov s naimenshey stoimostyu // Farmateka. - 2003. - № 6. - P. 34-38.

5. Marcevich S. Yu., Shal'nova S. A., Yakusevich $V$. $V$. i dr. Sravnitel'noe izuchenie effektivnosti dvuh preparatov enalaprila maleata u bol'nyh s myagkoj i umerennoj arterial'noj gipertoniej // Kardiovaskulyarnaya terapiya i profilaktika. - 2003. - № 2. - P. 33-37.

6. Nedogoda S. V., Sabanov S. V. Farmakoekonomika arterialnoy gipertenzii: ot globalnogo k chastnomu // Probl. standartizacii v zdravoohranenii. Byul. klin.-ekonom. analiza. - 2003. - № 2. - P. 25-29.

7. Abbate A., Biondi-Zoccai G. G. L., Baldi A. Pathophysiologic role of myocardial apoptosis in post-infarction left ventricular remodeling // J. Cell. Physiol. - 2002. - N 5. - P. 145-153.

8. Klingbeil A., Schneider M., Martus P. et al. A metaanalysis of the effects of treatment on left ventricular mass in essential hypertension // The Am. J. of Med. - 2003. - Vol. 115. - P. 41-46.

\title{
ПОРІВНЯЛЬНЕ ФАРМАКОЕКОНОМІЧНЕ ДОСЛІДЖЕННЯ ТА ОЦІНКА ГЕНЕРИКІВ ЕНАЛАПРИЛУ В ЛІКУВАННІ ХВОРИХ НА АРТЕРІАЛЬНУ ГІПЕРТЕНЗІЮ
}

\author{
I. В. Саханда ${ }^{1}$, К. Л. Косяченко, Т. С. Негода ${ }^{1}$, А. В. Кабачна ${ }^{2}$, Л. Л. Давтян ${ }^{2}$, \\ В. В. Гладишев ${ }^{3}$ С. В. Гладух $x^{4}$ (Київ, Запоріжжя, Харків) \\ ${ }^{1}$ Національний медичний університет імені О. О. Богомольця, Київ; \\ ${ }^{2}$ Національна медична академія післядипломної освіти ім. П. Л. Шупика, Київ; \\ 33апорізький державний медичний університет, Запоріжжя; \\ ${ }^{4}$ Національний фармацевтичний університет, Харків
}

Чисельність людей, хворих на серцево-судинні захворювання, останніми роками значно збыльшилась. За статистичними даними, хвороби серцево-судинної системи посідають одне 3 перших місць серед інших захворювань. Однією з основних патологій у кардіології $\epsilon$ гіпертонічна хвороба. Лікування артеріальної гіпертензії протягом тривалого періоду залишається важливим медико-соціальним та економічним завданням, важким фінансовим тягарем на самого пацієнта або на систему охорони здоров'я, у разі безкоштовного відпуску ліків. Група антигіпертензивних препаратів є однією із дороговартісних, у зв'язку з чим постає питання про економічно обгрунтовану терапію. Для науково обгрунтованого, а не емпіричного вибору препарату необхідне проведення клініко-економічних досліджень, що поєднують аналіз клінічної ефективності та економічної доступності. Найбільш прийнятним методом оцінки клінічної значущості різних препаратів є аналіз «витрати - ефективність». Стаття присвячена проведеним фармакоекономічним дослідженням, в яких наводиться порівняльна оцінка різним генерикам еналаприлу. Метою роботи було визначення та обгрунтування використання найбільш клінічноефективного та економічно доцільного генеричного препарату еналаприл. Методологічною основою дослідження була сучасна концепція маркетингових вивчення ринку лікарських засобів, методологія системного аналізу й наукового прогнозування економічних явищ. В процесі досліджень використані методи системного, соціологічного, економіко-статистичного аналізу, у тому числі заочного анкетування. В результаті проаналізовано обсяг продажу на фармацевтичному ринку серцево-судинних препаратів, вивчено структуру використання генериків еналаприлу у закладах охорони здоров'я та проведено фармакоекономічний аналіз (метод «витрати - ефективність») антигіпертензивної терапії генариків еналаприлу.

Ключові слова: фармакоекономічний аналіз; «витрати - ефективність»; артеріальна гіпертензія; артеріальний тиск; генерики; еналаприл. 


\title{
СРАВНИТЕЛЬНОЕ ФАРМАКОЭКОНОМИЧЕСКОЕ ИССЛЕДОВАНИЕ \\ И ОЦЕНКА ГЕНЕРИКОВ ЭНАЛАПРИЛА В ЛЕЧЕНИИ БОЛЬНЫХ С АРТЕРИАЛЬНОЙ ГИПЕРТЕНЗИЕЙ
}

\author{
И. В. Саханда ${ }^{l}$, К. Л. Косяченко, Т. С. Негода ${ }^{1}$, А. В. Кабачная ${ }^{2}$ Л. Л. Давтян ${ }^{2}$,
} B. В. Гладылеев ${ }^{3}$, Е. В. Гладух ${ }^{4}$ (Киев, Запорожье, Харьков)

${ }^{1}$ Национальный медицинский университет им. А. А. Богомольца, Киев; ${ }^{2}$ Национальная медицинская академия последипломного образования им. П. Л. Шупика, Киев;

зЗапорожский государственный медицинский университет, Запорожье;

${ }^{4}$ Национальный фармацевтический университет, Харьков

Количество людей, больных сердечно-сосудистыми заболеваниями, за последние годы значительно увеличилось. По статистическим данням, болезни сердечно-сосудистой системы занимают одно из первых мест среди других заболеваний. Одной из основных патологий в кардиологии является гипертоническая болезнь. Лечение артериальной гипертензии в течение длительного периода остаётся важной медико-социальной и экономической проблемой, тяжёлым финансовым бременем для самого пациента или системы здравоохранения в случае бесплатного отпуска лекарств. Группа антигипертензивных препаратов является одной из дорогостоящих, в связи с чем возникает вопрос об экономически обоснованной терапии. Для научно обоснованного, а не эмпирического выбора препарата необходимо проведение клиникоэкономических исследований, сочетающих анализ клинической эффективности и экономической доступности. Наиболее приемлемым методом оценки клинической значимости различных препаратов является анализ «затраты - эффективность». Статья посвящена проведённым фармакоэкономическим исследованиям, в которых приводится сравнительная оценка различных генериков эналаприла. Целью работы было определение и обоснование использования наиболее клинически эффективных и экономически целесообразных генерических препаратов эналаприла. Методологической основой исследования являлась современная концепция маркетингового изучения исследований рынка лекарственных препаратов, методология системного анализа и научного прогнозирования экономических явлений. В процессе исследований использованы методы системного, социологического, экономико-статистического анализа, в том числе заочного анкетирования. В результате были проанализированы объём продажи на фармацевтическом рынке сердечно-сосудистых препаратов, изучена структура потребления генериков эналаприла в учреждениях здравоохранения и проведён фармакоэкономический анализ (метод «затраты - эффективность») антигипертензивной терапии генериков эналаприла.

Ключевые слова: фармакоэкономический анализ; «затраты - эффективность»; артериальная гипертензия; артериальное давление; генерики; эналаприл. 